\title{
A Critical Approach to Freud and Psychoanalysis
}

\author{
Kübra YİĞİT TEKEL ${ }^{10}$ \\ Marmara University
}

"Psychology Without Spirit: The Freudian Quandary"

Samuel B. Sotillos, Chicago, 2018, Kazi Publications, 500p.

Sigmund Freud is one of the most influential figures in the field of psychology from his era to the present. He almost spent all his life creating and developing psychoanalytic theory. Psychoanalytic theory is related to not only treating mental problems but also to the fields such as language, religion, art, which are the dynamics of civilization. So much so that, Freud took a significant part of the basic concepts of psychoanalysis directly from mythology. In this respect, psychoanalysis is both an individual and a social movement.

When the psychoanalytic theory is considered from a historical point of view, it was shaped in a period when positivism was the principle standpoint as a scientific paradigm. Beginning with Newton, this change finds the spiritual approaches irrational and unscientific in the field of psychology as well. In his book 'Psychology Without Spirit: The Freudian Quandary', Samuel Bendeck Sotillos presents his readers with the inconsistency of the Freudian approach in its development and with comprehensive content on its ignorance of the spiritual and the sacred along with its struggle to become a science.

A practical psychotherapist in the Sotillos area is also a researcher with academic studies. He is an Advisor to the Institute of Traditional Psychology. He is also on the

\footnotetext{
1 Correspondence to: Kübra Yigit Tekel, Psychological Counselor, Bahcelievler İTO Science and Art Center, Ministry of National Education. Email: kbraygt06@gmail.com

Citation: Yiğit Tekel, K. (2019). A critical approach to freud and psychoanalysis. [Book review: Psychology Without Spirit: The Freudian Quandary] Spiritual Psychology and Counseling, 4, 359-362. http://dx.doi.org/10.37898/spc.2019.4.3.082R
} 
Editorial Board of the Journal of Spiritual Psychology and Counseling and Armonia. The focus of his work is; There is interaction between comparative religion, perennial philosophy, spirituality and psychology. He has a book called 'Behaviorism: the Quandary of a Psychology without a Soul'. He is the editor of Psychology and the Perennial Philosophy. His writing has appeared in Sacred Web, Sophia,Parabola, Resurgence,Temenos Academy Review and Studies in Comparative Religion. He has travelled throughout the world to visit sacred sites and had contact with noted spiritual authorities.

The book consists of 27 chapters including the introduction and conclusion. The headings are carefully selected for each chapter. In the introduction, the facts behind why Freudian psychology started out with treatment purpose are discussed. In chapter one and two: Darwinian and Copernican way of thinking and the secular point of view created by modernism paved the way for a psychology approach that is far from spirituality. Freud would claim to fill this spiritual gap with psychoanalysis. The author states that in order to understand psychoanalysis, it should be considered together with the Copernican and Darwinian revolutions and that psychoanalysis can be both the cause and the consequence of a mental disorder in the geography. In chapter three, four and five, he claims that Freudianism is not only Freud's approach but also a secret organization formed by the people influenced by it. He mentions that Freud thought of psychoanalysis as his own invention and severely restricted its right of use. He criticizes that Freud has been considered to be a hero by keeping psychoanalysis secret and obscure just like his own life. In chapter six and seven, he criticizes that Freud rejects the transcendent and divine (imago dei) side of human beings in his own metapsychology, limits him to the 'psychological man'; rejecting human spirit and spirituality and reducing everything to psychological factors. In chapter eight and nine, he addresses the attempt of psychoanalysis to fill the gap that systematically damages religion and spirituality as a secular religion under the name of science. He criticizes that Freud transformed metaphysics into psychology and expressed it as metapsychology. In chapter ten, it is stated that psychoanalysis has limited the spirituality and spirit of the individual to the empirical ego. The author says that it is wrong to classify human identity with three concepts. In chapter eleven, it is emphasized that psychological literature sees spirituality as a mental problem, rather than a transcendence assessment for those who can be considered as spiritual and religious figures, by leaning towards what will be the most appropriate clinical diagnosis for them. He criticizes the idea that people experiencing a variety of spiritual and mystical experiences are suffering from psychopathology with the rise of secularism and reductionism.

In chapter twelve, he emphasizes how normality is considered equal to neurosis in Freudian psychology and psychopathology is glorified. In chapter thirteen, he suggests 
the similarity of speech therapy and the confession process. He compares the secretive and accepting attitude of a priest to the psychoanalyst's relationship with the patient. Freud's attitude of creating metapsychology from metaphysics is also seen here. Psychiatrist replaces the priest while psychoanalysis replaces the religion. In chapter fourteen and fifteen, psychoanalysis states that evil is a step that individualizes the human and it is pointed out that listening to bad experiences without interfering and judging in the process shows that psychoanalysis is not interested in spirituality. In chapter sixteen, it is told that Freud was Jewish and limited to a Jewish environment, but preferred atheism. The author states that this complex situation may have an effect on the complexity of his theory. In chapter 17, the author explains that Anna Freud called psychoanalysis as Jewish science in an opening speech as well as Guenon's question "Why Jews are the pioneers of innovations?". In this chapter, it is emphasized that the impact of Freud's childhood experiences may be the reason behind the emergence of psychoanalysis as Jewish science. In chapter 19, it is questioned whether psychoanalysis is a science or a pseudoscience, in other words, a religion.

In the last five chapters, he states that many failed case histories were put forward as if they were successful to create the so-called scientific foundations of psychoanalysis. It is emphasized that the psychoanalyst must go through psychoanalysis to perform psychoanalysis, but Freud never did that; he carried out self-analysis instead but did not complete it either, which contradicts with psychoanalysis. He addressed how the cocaine mistake in Freud's life was reflected on psychoanalysis. He reveals that case studies were not real but fiction to form a theoretical background. He criticizes the fact that all problems are reduced to sexuality in Freudian psychology.

This book has a very deep and comprehensive content in the fields of psychology, theology and philosophy. In addition, it is seen that the author has a command of the etymology of spirituality, psychology, and spiritual psychology. All the information in the book has been put forward with a scientific basis. The footnote and bibliography of the book consist of 184 pages, which shows that the book is very comprehensive and profound. Further reading is considered necessary to understand the book correctly. Each chapter includes a sufficient number of different views. Although the author does not entirely adopt a positivist paradigm, it appears that he substantially meets the conditions of this paradigm. It is thought that he tries to maintain his objective attitude. However, with an intuitive estimate, it can be stated that the author is inclined to spiritual-based approaches.

Freud claims that human behavior and motivation lies in the deepest levels. Many works bear the traces of its author's life. The data that supports the psychoanalytic theory are largely based on his own analysis. Therefore, in order to understand psychoanalysis, one has to examine Freud in detail. There are numerous sources 
about Freud. Some of these sources are Ernest Jones's comprehensive three-volume 1450-page book, The Life and Work of Sigmund Freud, published memoirs of former patients Fragments of an Analysis with Freud, and a number of biographical materials including the volumes of published correspondences. (Yalom, 2000. p. 120).

The psychoanalytic theory involves the use of methods that will reveal the unconscious to a great extent. Modernists believe in the objective reality that can be observed and systematically known. In Freudian psychoanalysis which was influenced by this movement, he argues that people will face a problem when they move away from known objective norms and therefore they will need therapy. Centuries ago, Freud, Adler and Jung became a part of this great paradigm of change that led to a great transformation in psychology as well as philosophy, medicine and even art.

Regardless of a person's spiritual view, this view is the force that allows an individual to make sense of the universe and find a purpose in life. Psychoanalytic therapy emphasizes the importance of biological and impulsive factors by ignoring social, cultural and interpersonal factors. While spirituality has been an inseparable part of mental health throughout the history of humanity, modern psychology influenced by materialism has completely excluded spirituality and religion.

Spiritual Oriented Psychotherapy book published by the American Psychological Association (APA) in 2007 was the first of the spiritually oriented psychotherapy approaches and it is an indication that this field has begun to develop (Ekşi, Kaya, and Çiftçi, 2016). This book also provides guidance on spiritually oriented psychotherapy. The book titled Manevi Yönelimli Psikoterapi ve Psikolojik Danışma (Spiritually Oriented Psychotherapy and Psychological Counseling), which was published in 2016 in our country, is also an indicator of the fact that spiritually oriented psychotherapy field is open to development. Spirituality and religion have been considered as an important variable in behavioral sciences for the last 30 years. Considering our rich cultural and spiritual heritage, carrying out such studies in Turkey will make a great contribution to the field.

\section{References}

Corey G. (2008). Psikolojik danışma psikoterapi kuram ve uygulamaları. (Ergene T. Çev) Ankara: Mentis Yayıncılik

Ekşi, H. \& Kaya, Ç. (2016). Manevi yönelimli psikoterapi ve psikolojik danışma. İstanbul: Kaknüs Yayıncilik.

Yalom, I. D. (2001). Varoluşçu psikoterapi, İstanbul: Kabalcı Yayınevi. 